\title{
Sumber Daya Mineral Pasir Kuarsa Sebagai Alternative Pengembangan Usaha Pertambangan Di Daerah Kading Kabupaten Barru
}

\author{
Muh. Darwis Falah' ${ }^{1}$, Muzaki' ${ }^{2}$ \\ ${ }^{1)}$ PPs Pendidikan Kependudukan dan Lingkugan Hidup, Universitas Negeri Makassar \\ ${ }^{2)}$ Manajemen Informatika, STMIK Handayani Makassar \\ Email :darwisfalah@gmail.com
}

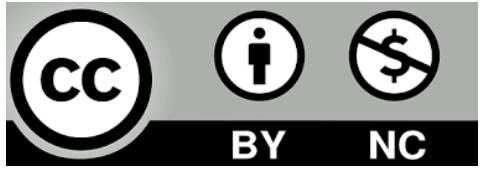

() 2020 - UEJ Program Studi Pendidikan Kependudukan dan Lingkungan Hidup Universitas Negeri Makassar. Ini adalah artikel dengan akses terbuka dibawah Licensi CC BY-NC-4.0(http:/creativecommons.org/licenses/by-nc/4.0)

\begin{abstract}
Abstrak.
Tujuan penelitian ini untuk merancang kewirausahaan suatu usaha pertambangan sumber daya mineral pasir kuarsa yang berwawasan lingkungan. Lokasi penelitian di daerah Kading Kecamatan Tanete Riaja. Penelitian dilakukan dengan cara survey dan pemetaan. Pembangunan usaha pertambangan yang berwawasan lingkungan mensyaratkan adanya pengelolaan sumber daya yang bijaksana. Di sisi lain usaha pertambangan tersebut memberikan resiko terhadap kerusakan lingkungan. Olehnya tindakan pengendalian lingkungan adalah upaya yang harus diperhitungkan dalam perencanaan pertambangan yang berwawasan lingkungan. Berdasakan hasil penelitian endapan pasir kuarsa yang terdapat di daerah penelitian menunjukkan kadar $\mathrm{SiO}_{2}=(85-90) \%$, sehingga dapat digunakan sebagai bahan baku pembuatan semen di Pabrik Semen Bosowa dan Pabrik Semen Tonasa. Pasir kuarsa tersebut menyebar pada daerah seluas 30 ha, mempunyai cadangan terukur 5.175 .000 ton, mining recovery $90 \%$ sehingga cadangan layak tambang adalah 4.657.500 ton. Penambangan yang cocok diterapkan di wilayah penelitian adalah tambang terbuka dengan system teras-teras, penggalian dilakukan dengan metode back filling. Peralatan tambang yang diperlukan adalah excavator dan dump truck. Rencana produksi 120.000 ton/tahun, sehingga umur tambang 38,81 tahun. Rencana pemasaran PT Semen Tonasa Pangkep dan PT Semen Bosowa Maros untuk bahan baku pengoreksi industri semen, harga jual Rp 100.000 per ton logo gudang pabrik semen.
\end{abstract}

Kata kunci : Sumber Daya Mineral, Cadangan, Endapan Pasir.

\section{Pendahuluan}

Pasir kuarsa merupakan bahan galian industri yang termasuk dalam bahan galian batuan, dapat digunakan sebagai bahan baku tambahan (adevtif) untuk pembuatan semen Portland dan gelas serta bahan tahan api dan bahan konstruksi bangunan. Pasir kuarsa di daerah Bunne Desa Kading Kecamatan Tanete Riaja telah diketahui sejak pemetaan geologi regional dilakukan oleh Pusat Penelitian dan Pengembangan Geologi Departemen Pertambangan dan Energi Republik Indonesia (Rab Sukamto, 1982).

Pabrik semen Portland PT Semen Tonasa dan PT Semen Bosowa menggunakan pasir kuarsa sebagai bahan baku pengoreksi (tambahan), untuk pengoreksi pada tanah liat bila 
kadar silikatnya rendah. Penggunaan pasir kuarsa saat sekarang pada pabrik semen tersebut rata-rata 500.000 ton/tahun yang diperoleh dari Kabupaten Pangkep, namun potensinya terbatas sehingga perlu mencari potensi ditempat lain.

Peluang usaha ini perlu dimanfaatkan karena dapat membuat lapangan kerja. Namun kegiatan usaha pertambangan dikhawatirkan akan berdampak kepada kerusakan lingkungan. Untuk itu tujuan penelitian ini untuk merancang wirausaha pertambangan pasir kuarsa yang berwawasan lingkungan. Pembangunan usaha pertambangan yang berwawasan lingkungan mensyaratkan adanya pengelolaan sumber daya mineral yang bijaksana. Di sisi lain usaha pertambangan tersebut memberikan resiko terhadap kerusakan lingkungan. Olehnya tindakan pengendalian lingkungan adalah upaya yang harus diperhitungkan dalam perencanaan pertambangan yang berwawasan lingkungan. Untuk melakukan pengembangan usaha pertambangan yang berwawasan lingkungan diperlukan kajian tentang kelayakan teknik, ekonomi dan lingkungan (Ardianto, 2017).

Daerah penelitian secara administrative terletak di daerah Bunne Desa Kading, Kecamatan Tanete Riaja. Secara geografi daerah tersebut terletak pada posisi: $4^{0} 31^{\prime} 15^{\prime \prime}-4^{0}$ 31' 45" Lintang Selatan dan $119^{0} 40^{\prime} 25^{\prime \prime}$ - $119^{0} 40$ ' 50"' Bujur Timur dari Greenwich. Daerah tersebut terletak $15 \mathrm{~km}$ di sebelah tenggara kota Barru. Daerah ini dapat dicapai dari kota Barru dengan kendaraan bermotor melalui jalanan propinsi yang beraspal sepanjang $18 \mathrm{~km}$ dengan waktu tempuh menggunakan kendaraan bermotor 0,5 jam. Untuk mencapai daerah penelitian dari jalanan Provinsi hanya bisa dicapai dengan jalan kaki melalui pendakian sejauh $1 \mathrm{~km}$.

\section{Kajian Teori}

Menurut Sutardji (2009) sumber daya mineral adalah endapan mineral atau batuan yang diharapkan dapat dimanfaatkan secara nyata. Sumber daya mineral dengan keyakinan geologi tertentu dapat berubah menjadi cadangan setelah dilakukan pengkajian kelayakan tambang dan memenuhi kriteria layak tambang. Sumber daya mineral menopang banyak kebutuhan hidup manusia, tanpa keberadaannya maka manusia akan mengalami kesulitan.

Menurut Sukandarrumidi (2004) sumber daya mineral pasir kuarsa memegang peranan cukup penting bagi industri, baik sebagai bahan baku utama maupun penolong. Sebagai bahan baku utama, pasir kuarsa dipakai oleh industri semen, kaca lembaran, botol dan pecah-belah. Sedangkan sebagai bahan baku penolong dipakai dalam pengecoran logam, dan industri lainnya. Hasil survey yang dilakukan oleh Pusat Pengembangan Teknologi Mineral dalam kurun waktu 1981 - 1993 menunjukkan konsumsi pasir kuarsa meningkat sekitar 28,30 \% per tahun.

Menurut Supriatna S. dan M. Arifin (1997) pasir kuarsa adalah sumber daya mineral mineral yang terdiri atas kristal-krital silica $\left(\mathrm{SiO}_{2}\right)$ dan mengandung senyawa pengotor yang terbawa selama proses pengendapan. Pada umumnya senyawa pengotor tersebut terdiri atas oksida besi, oksida kalsium, oksida alkali, oksida magnesium, lempung, dan zat organic. Sifat fisik pasir kuarsa berwarna putih, kekerasan 7 skala Mohs, berat jenis 2,6, titik lebur kurang lebih $1.715^{\circ} \mathrm{C}$ dan bentuk kristal hexagonal. Komposisi kimia SiO2 (55 - 99) \%.

Perhitungan cadangan dilakukan berdasarkan system klasifikasi sumber daya mineral dan cadangan menurut SNI 13-4726-2011. System klasifikasi ini didasarkan pada keyakinan geologi dan kelayakan tambang. Berdasarkan klasifikasi tersebut maka cadangan dibagi dua yakni; cadangan terkira (probable reserves) dan cadangan terbukti (proven reserves).

Menurut Suyanto \& Utomo (2003) cadangan terukur adalah sumber daya mineral terukur yang berdasarkan studi kelayakan tambang dengan memperhitungkan sebaran nilai resistivitas sebenarnya sehingga semua factor yang terkait telah terpenuhi, sehingga 
penambangan dapat dilakukan secara ekonomik. Sedangkan cadangan terkira adalah sumberdaya mineral terunjuk dan sebagian sumberdaya mineral terukur yang tingkat keyakinan geologinya masih lebih rendah. Cadangan terukur adalah penafsiran keberadaan model bawah permukaan,

Menurut Lefond, Stanley J. (1975) bahan baku utama pembuatan semen Portland terdiri dari: Batu gamping (limestone) $=80 \%$, Lempung $($ clay $)=20 \%$, Gipsum $($ gypsum $)=5 \%$. Bahan baku koreksi (bahan tambahan bila diperlukan) terdiri dari: Pasir kuarsa (silica sand) = $5 \%$. Pasir besi (iron sand) $=1 \%$. Proses pembuatan semen Portland diawali dengan melakukan pemecahan bahan baku dengan mesin pemecah batu sampai pada ukuran 200 mesh berupa umpan, kemudian dilakukan pemanasan di klin sampai pada temperature 1.400 ${ }^{\circ} \mathrm{C}$, setelah pendinginan menghasilkan klinker kemudian ditambahkan gypsum $(3-5) \%$.

Pembangunan berwawasan lingkungan merupakan suatu upaya memaksimalkan potensi Sumber Daya Alam yang ada secara terencana, bertanggung jawab, dan sesuai dengan daya dukungnya. Kemakmuran rakyat, kelestarian fungsi, dan keseimbangan lingkungan hidup merupakan hal yang utama dalam mendukung pembangunan berwawasan lingkungan sebagai wujud penerapan keberlanjutan (Cahyani \& Aji, 2018). Perhitungan atau pertimbangan biaya dan kerusakan lingkungan juga merupakan instrument penting untuk mencapai pembangunan yang berkelanjutan. Otto Soemarwoto (2004) mengemukakan bahwa perinsip dasar dari pembangunan berkelanjutan haruslah mengakomodasi aspek konservasi, rasionalisasi, dan kepentingan soaial.

\section{Metode Penelitian}

Penelitian eksplorasi dilakukan dengan metode survey lapangan dan pemetaan, ditempuh melalui tahapan-tahapan: Tahap persiapan yaitu mempelajari hasil-hasil penyelidikan terdahulu. Tahap pekerjaan lapangan yaitu kegiatan pengumpulan data-data lapangan. Pengumpulan data lapangan meliputi pemetaan geologi, penghitungan cadangan, dan pengambilan contoh. Tahap analisa yaitu analisa kimia dan fisika contoh pasir kuarsa serta analisa data-data lapangan. Tahap penyusunan laporan.

Studi kelayakan penambangan pasir kuarsa, meliputi: Studi rencana penambangan dan analisis kelayakan ekonomi. Studi rencana penambangan terdiri dari metode dan tatacara penambangan, rencana produksi, peralatan yang digunakan, umur tambang, rencana pemanfaatan sumber daya mineral.

\section{Hasil Penelitian}

\section{Geologi Daerah Penelitian}

Daerah penelitian secara administrative termasuk dalam wilayah Desa Kading. Penduduk Desa Kading berjumlah 3.264 jiwa (laki-laki 1.581 jiwa dan perempuan 1.683 jiwa) dengan jumlah keluarga $786 \mathrm{KK}$, menyebar pada dusun-dusun : Bunne, Pasarbaru, Tokkene, dan Rumpiae. Luas wilayah secara keseluruhan 22,69 $\mathrm{km}^{2}$.dengan kepadatan 144 jiwa/km² (Kecamatan Tanete Riaja dalam Angka, 2013).

Desa Kading berdasarkan kedudukan garis lintang merupakan daerah yang beriklim tropis, dan termasuk dalam pola iklim pesisir pantai Barat Sulawesi Selatan. Musin hujan terjadi pada bulan Desember hingga bulan April, dan musim kemarau terjadi pada bulan Juni hingga bulan Nopember, antara kedua musin tersebut terdapat musim pancaroba. Curah hujan tahunan rata-rata $2.957 \mathrm{~mm} / \mathrm{th}$ dan hari hujan tahunan rata-rata $97 \mathrm{~h} /$ th (Kabupaten Barru dalam Angka, 2013).

Daerah penelitian merupakan daerah perbukitan yang termasuk dalam kawasan Areal Penggunaan Lain (APL), yang merupakan daerah perkebunan, bervegetasi rumputan, semak- 
belukar dan sedikit pepohonan. Pada umumnya tumbuhan-tumbuhan di daerah penelitian adalah tumbuhan budidaya penduduk yang terdiri dari: jambu mente, mangga, nangka. dan tanaman musiman pisang. Fauna yang terdapat di dalam wilayah eksplorasi dan sekitarnya yang merupakan fauna budidaya dan non budidaya. Fauna non budidaya.

Daerah penelitian merupakan rangkaian dari daerah perbukitan Bulu Bunne dengan bentuk fisiografi perbukitan yang berarah baratlaut-tenggara, bagian utaranya dibatasi oleh Sungai Umpunge dan di bagian selatan di batas oleh Jalan raya provinsi, berada pada ketinggian 75 - $155 \mathrm{~m}$ dpl. Sungai Umpung merupakan sungai permanent yang pada musim kemarau debit air sungainya kecil. Tekstur topografi agak kasar dan relief topografi agak tinggi. Daerah penelitian merupakan daerah berlereng landai sampai agak terjal, bentuk lembah lebar dengan punggungan yang tumpul.

Daerah penelitian berdasarkan litostratigrafi disusun oleh satuan batuan: Serpih, Batu pasir Kuarsa, dan Batu gamping. Satuan Serpih tersusun dari serpih dan batulempung berselingan batulanau, merupakan tipe sediment flysch. Pada umumnya menunjukkan struktur turbidit, umurnya diperkirakan Kapur Atas. Formasi ini tebalnya tidak kurang dari $1.000 \mathrm{~m}$, tertindih secara tidak selaras dengan batuan yang lebih muda, sebarannya di daerah bagian selatan daerah penelitian. Satuan batuan ini mempunyai kesamaan ciri litologi dengan Formasi Balangbaru (Rab Sukamto, 1982).

Satuan Batu pasir Kuarsa tersusun dari batupasir kuarsa, berselingan batulanau dan batulempung dengan sisipan lapisan batu gamping. Batuannya mengandung fosil Maluska dan Foraminifera yang menunjukkan umur Eosen, diendapkan dalam lingkungan paralaks sampai dangkal, ketebalan formasi ini berdasarkan penampang geologi adalah $150 \mathrm{~m}$, tertindih secara selaras oleh Satuan Batugamping, sebarannya merupakan daerah prospek pasir kuarsa di daerah bagian tengah. Satuan Batu pasir Kuarsa ini mempunyai kesamaan ciri litologi dengan Formasi Mallawa (Rab Sukamto, 1982).

Satuan Batu gamping tersusun dari batu gamping kalsirudit, batu gamping bioklastika dan kalkarenit. Batuannya berwarna putih sampai abuabu, sebagian berlapis baik, setempatsetempat bersisipan dengan breksi batugamping pasiran, mengandung fosil Moluska dan Foraminifera yang menunjukkan umur Eosen Awal sampai Miosen Tengah dengan lingkungan pengendapan neretik. Tebal formasi ini dari penampang geologi tidak kurang dari $500 \mathrm{~m}$, sebarannya di daerah bagian utara. Satuan Batugamping ini mempunyai kesamaan ciri litologi dengan Formasi Tonasa (Rab Sukamto, 1982).

Struktur geologi daerah penelitian merupakan daerah perlipatan homo klinal yang tersesarkan dan terkekarkan dengan intensitas rendah. Perlipatan secara umum berarah barat laut-tenggara miring kearah timur laut dengan kemiringan $(15-30)$ derajat.

\section{Sumber Daya Mineral Pasir Kuarsa Daerah Penelitian}

Endapan pasir kuarsa di daerah eksplorasi menyebar di daerah Bulu Bunne dan sekitarnya, pada topografi daerah perbukitan cuesta dengan vegetasi semak-belukar dan padang-rumput serta sedikit pepohonan. Singkapan yang jelas dapat diamati di daerah Bulu Bunne. Singkapan tersebut berkaitan erat dengan proses erosi anak Sungai Umpunge dan Sungai Rumpiae. Endapannya berwarna putih keabuabuan sampai kecoklatan, bila lapuk menghasilkan soil berwarna abuabu kecoklatan, berukuran pasir halus sampai kasar, bentuk butir bersudut tanggung sampai menyudut, agak lunak sampai keras (dapat digali secara manual maupun semi mekanis), strukutur geologi batuan berlapis dengan kedudukan baratlaut-tenggara miring ke arah timurlaut sebesar $10-20$ derajat, struktur sedimen yang dapat diamati adalah laminasi sejajar dan pelapisan silang-siur. Endapan pasir kuarsa tersebut terbentuk dari pelapukan laterik batupasir arkosik (batupasir kuarsa), berdasarkan ciri litologinya dapat dikorelasikan dengan Batuan Formasi Mallawa. 


\section{Kualitas}

Kualitas sumber daya mineral pasir kuarsa ditentukan berdasarkan oleh sifat kimia (komposisi kimia) dan sifat fisika. Hasil analisa kimia dan fisika dari pasir kuarsa tersebut dibandingkan dengan spesifikasi yang diperlukan untuk industri.

Hasil analisa kimia contoh pasir kuarsa daerah penelitian menunjukkan komposisi:

$\mathrm{SiO}_{2}=87,1 \%, \mathrm{Al}_{2} \mathrm{O}_{3}=5,1 \%, \mathrm{Fe}_{2} \mathrm{O}_{3}=1,1 \%, \mathrm{CaO}=0,1 \%, \mathrm{MgO}=0,7 \%, \mathrm{~K}_{2} \mathrm{O}=0,1, \mathrm{Na}_{2} \mathrm{O}$ $=0,1 \%$

Komposisi mineralnya adalah: kuarsa $=52 \%$, feldspar plagioklas $=3 \%$, kuarsit $=2 \%$, mineral lempung $=25 \%$, serisit $=5 \%$, mineral opak $=3 \%$, oksida besi $=10 \%$ serta sedikit mineral mafik, berat jenis 2,3 ton $/ \mathrm{m}^{3}$. Hasil analisa fraksi menunjukkan: fraksi pasir: sangat kasar = $1,61 \%$, kasar $=7,85 \%$, sedang $=18,93 \%$, halus $=60,25 \%$, sangat halus $=5,97 \%$, lempung $=4,76 \%$.

Berdasarkan hasil analisa contoh pasir kuarsa tersebut diatas $\left(\mathrm{SiO}_{2}\right.$ kurang dari $95 \%$ dan $\mathrm{Fe}_{2} \mathrm{O}_{3}$ lebih besar dari $1 \%$ ), sehingga pasir kuarsa di daerah penelitian hanya dapat digunakan sebagai bahan baku pengoreksi pembuatan semen portland. Pasir kuarsa di industri semen portland digunakan sebagai pengontrol kandungan silica dalam semen yang dihasilkan. Jumlah pasir kuarsa yang dicampur dengan bahan baku semen lainnya bervariasi, bergantung kepada kandungan silica bahan baku semen lainnya. Akan tetapi secara umum dapat ditentukan dengan komposisi atau perbandingan 66,5 $\mathrm{kg}$ pasir kuarsa untuk 1 ton produk semen

\section{Cadangan dan umur tambang}

Cadangan adalah endapan bahan galian yang telah diketahui ukuran, bentuk, sebaran, kualitas dan kuantitasnya dan secara ekonomis, teknis, hukum, lingkungan dan sosial dapat ditambang pada saat perhitungan dilakukan (Rahmatillah, et. al, 2019).

Perhitungan cadangan yang akan diuraikan adalah perhitungan yang dapat ditambang (mineable reserve). Untuk mengetahui besarnya cadangan pasir kuarsa, perhitungan dilakukan dengan metode luas pengaruh terhadap penampang terukur dan parameter geologi lainnya. Cadangan adalah hasil perkalian volume dengan berat jenis dan factor konkresi. Berdasarkan data lapangan, sebagai berikut: luas penyebaran $=30 \mathrm{ha}=300.000 \mathrm{~m}^{2}$, ketebalan rata-rata $=$ $10 \mathrm{~m}$, konkresi factor $75 \%$, berat jenis $=2,3$. Sehingga diperoleh cadangan terukur endapan pasir kuarsa daerah penelitian adalah $=5.175 .000$ ton.

Menurut Machali Muhsin (1999), umur tambang adalah waktu yang diperlukan untuk melakukan kegiatan pertambangan. Besarnya atau lamanya ditentukan atas perbandingan cadangan dengan produksi dikali mining recovery.

Berdasarkan data cadangan terukur dengan mining recovery $90 \%$, sehingga cadangan layak tambang $($ mineable $)=4.657 .500$ ton. Jika produksi direncanakan 120.000 ton/tahun atau $10.000 \mathrm{ton} /$ bulan atau 416,67 ton/hari kerja, maka umur tambang $=38.81$ tahun atau 465,72 bulan. Bila hari 288 hari per tahun, sehingga produksi bisa berlangsung 11.177,28 hari.

\section{Usulan Penambangan Pasir Kuarsa}

Menurut Suyartono (2003), usulan penambangan berdasarkan pertimbangan tetap tersediannya pengadaan produksi dan kelancaran operasi penambangan serta tetap terjaminnya lingkungan dari dampak negatif penambangan, maka usulan penambangan pasir kuarsa meliputi: Pembukaan tambang, pemindahan tanah penutup dan pengambilan pasir kuarsa, pemuatan dan pengangkutan, jalan tambang dan tata letak tambang.

Pembukaan tambang yang dimaksud adalah kegiatan pembersihan lokasi, baik secara manual maupun mekanis dalam rangka persiapan penambangan. Untuk mencapai lokasi penambangan terlebih dahulu dibuat jalan rintisan secara manual. Jalan rintisan ini sebaiknya 
diatur agar nantinya dapat merupakan jalan angkut utama. Kayu hasil pembersihan dan rintisan sebaiknya diatur dan dikumpulkan pada suatu tempat tertentu untuk memudahkan penggunaannya dalam pembukaan tambang dan penambangan.

Pemindahan tanah penutup atau lapisan penutup dilakukan secara mekanis dengan menggunakan bulldozer. Setelah endapan pasir kuarsa tersingkap digunakan excavator untuk mengeduk atau mengeruk. Pasir kuarsa merupakan batuan telah mengalami pelapukan, sehingga batuannya dapat dikeruk atau dikeduk tanpa peledakan. Pengambilan pasir kuarsa dapat dengan menggunakan excavator, kemudian ditumpuk pada tempat penampungan. Pemindahan tanah penutup dan pengambilan pasir kuarsa dengan menggunakan metode cut and filling, tinggi jenjang harus disesuaikan dengan spesifikasi alat muat.

Bongkah-bongkah batu pasir kuarsa hasil galian excavator ataupun secara manual terlebih dahulu dipecahkan menjadi pasir kuarsa, kemudian dimasukkan ke alat angkut (dump truck) dengan menggunakan alat muat loader atau excavator. Pasir kuarsa tersebut diangkut ke unit penampungan (stock file) dengan dump truck. Hal yang harus diperhatikan dalam aktifitas ini adalah sinkronisasi jenis alat dan jumlah alat angkut, sehingga salah satunya tidak menganggur ataupun terlampau sibuk. Hal ini dimaksudkan agar sasaran produksi tercapai.

Tata letak dan jalan tambang merupakan salah satu sarana yang sangat menentukan kelancaran dan efektifitas kegiatan penambangan. Penentuan tata letak tambang harus menjamin kedudukan permukaan kerja penambangan berikutnya serta kemajuannya, kedudukan jalan tambang dan kedudukan unit penambangan.

Pemilihan lintasan jalan tambang yang menghubungkan daerah front penambangan dan penimbunan, perlu memperhatikan: Melalui daerah yang landai dengan kemiringan lereng maksimun $8 \%$, sehingga tidak terlalu memaksa alat angkut. Mengurangi belokan, tanjakan dan penurunan. Merupakan jalan yang jaraknya terpendek menuju penimbunan. Bila mungkin, memanfaatkan dan meningkatkan jalan yang telah ada.

Berdasarkan sifat fisik dari tanah penutup dan keadaan endapan pasir kuarsa, maka cara penambangan yang cocok diterapkan di wilayah penelitian adalah tambang terbuka (open pit mining), menggunakan metode back filling secara berjenjang. Tinggi jenjang disesuaikan dengan alat dan endapan pasir kuarsa.

Penambangan dimulai dari daerah yang tinggi dengan tujuan untuk mempermudah tempat kedudukan penambangan. Penambangan dapat dilakukan pada musim kemarau dan musim hujan, mengingat cara penambangan yang mudah diatur.

\section{Peralatan Tambang:}

Peralatan tambang yang diperlukan, terdiri dari: Bulldozer, excavator, dan dump truck. Bulldozer yang akan digunakan adalah jenis komatsu, type D $65 \mathrm{E}-8$, kemampuan dorong tanah $244 \mathrm{~m}^{3} / \mathrm{jam}$. Bulldozer tersebut digunakan untuk kegiatan pembersihan tempat kerja dan pengupasan lapisan penutup. Target produksi 416,66 ton/hari, maka volume tanah/batuan yang harus didorong setiap hari adalah $25 \mathrm{~m}^{3} /$ hari atau $3,13 \mathrm{~m}^{3} / \mathrm{jam}$ (jam kerja $8 \mathrm{jam} / \mathrm{hari}$ ). Jadi jumlah bulldozer yang akan digunakan adalah 0,01 unit ditambah kegiatan pembersihan lahan, sehingga diperlukan $=1$ unit. Boulldozer dapat digunakan pula untuk membantu penggalian batupasir kuarsa.

Excavator yang akan digunakan adalah type PC 300 - 3. Alat tersebut digunakan dalam penggalian dan pemuatan batupasir kuarsa (pasir kuarsa) dengan kemampuan produksinya adalah 57 ton/jam. Untuk mencapai target produksi pasir kuarsa 416,66 ton/hari, maka produksi harus 52 ton/jam. Untuk itu dibutuhkan excavator type PC $300-3$ sebanyak 0,91 unit $=1$ unit.

Dump truck digunakan untuk kegiatan pengangkutan pasir kuarsa akan dioperasikan alat dump truck tipe PS 190 merek Mitsubishi dengan kemampuan produksi 80 ton/hari 
(cyrcle time 4 kali per hari). Untuk mencapai target produksi 416,66 ton/hari, maka jumlah dump truck yang dibutuhkan adalah 5,2 unit atau 6 unit. Dump truck bisa pula difungsikan untuk pengangkutan lapisan penutup bila diperlukan.

\section{Sarana Penunjang}

Untuk menunjang kelancaran kegiatan usaha pertambangan dan penambangan pasir kuarsa maka diperlukan sarana dan prasarana, seperti:

a. Jalan Tambang, merupakan jalan penghubung antara lokasi penambangan dengan tempat penumpukan sementara pasir kuarsa, atau sebagai jalan pengangkutan pasir kuarsa dan bahan-bahan lainnya.

b. Tempat penumpukan lapisan penutup (top soil).

c. Tempat penumpukan pasir kuarsa (stock file).

d. Kendaraan lapangan dan mesin listrik.

e. Kantor, gudang, bengkel, perumahan karyawan dan sarana penunjangnya.

f. Alat komunikasi dan keselamatan serta kesehatan kerja.

\section{Organisasi Tenaga Kerja}

Struktur organisasi adalah merupakan suatu susunan ataupun hubungan antar komponen berbagai bagian dan posisi dalam sebuah organisasi terutama dalam pengelolaan suatu perusahaan khususnya dalam bidang usaha pertambangan.

Struktur organisasi bertujuan untuk mengatur setiap kegiatan dan personilnya, sehingga pelaksanaan pekerjaan yang dibebankan kepada masing-masing personil dapat dipertanggungjawabkan. Dengan adanya kegiatan pertambangan ini maka akan memerlukan banyak tenaga kerja, baik tenaga kerja menengah maupun tenaga ahli sesuai dengan kebutuhan perusahaan. Tenaga kerja dapat dipenuhi sebagian dari daerah setempat dan sekitarnya, sedangkan tenaga kerja dengan kualifikasi khusus bila tidak terdapat di daerah setempat akan diperoleh dari tempat lain.

Adapun struktur organisasi dan tenaga kerja pada Pertambangan Pasir Kuarsa di Daerah Penelitian yang diusulkan, terdiri dari: Direktur . Kepala Teknik Tambang. Bagian Umum terdiri dari seksi: Kepegawaian, Keuangan, Pemasaran. Bagian Produksi terdiri dari seksi: Perawatan, Pengendalian Mutu, Operasi Produksi dan Pengolahan. Jumlah personil 42 orang dan gaji per tahun diproyeksikan Rp 1.128.000.000.

\section{Prospek Pemasaran}

PT Semen Tonasa di Pangkep dan PT Semen Bosowa di Maros merupakan pabrik semen yang telah melakukan pengkajian pemanfaatan bahan galian pasir kuarsa Kabupaten Barru untuk bahan baku tambahan pembuatan semen portland. Hasilnya adalah pasir kuarsa Kabupaten Barru dapat digunakan sebagai baku tambahan pembuatan semen Portland type I guna pengoreksi pada bahan baku tanah liat yang masih kurang kadar $\mathrm{SiO}_{2}$. Kebutuhan pasir kuarsa 500.000 ton/tahun untuk pengoreksi bahan baku semen.

Total cadangan terukur pasir kuarsa daerah studi adalah 5.175.000 ton dan volume lapisan penutup adalah $300.000 \mathrm{~m}^{3}$, sehingga ratio lapisan penutup (overburden ratio) adalah $0,06 \mathrm{~m}^{3} /$ ton. Bila hari kerja 288 hari per tahun atau 24 hari per bulan, sehingga produksi bisa berlangsung 11.177,28 hari dengan produksi 416,66 ton/hari, dan jika jam kerja 8 jam/hari, maka produksi 52,07 ton/jam. Harga penjualan bahan galian pasir kuarsa logo gudang pabrik semen adalah $\mathrm{Rp} 100.000$ per ton. Kualifikasi standar pasir kuarsa yang diperlukan pabrik semen adalah $\mathrm{SiO}_{2}$ lebih besar $85 \%$.

Produksi jangka panjang akan disesuaikan dengan perkembangan kebutuhan bahan galian pasir kuarsa untuk pabrik semen. Namun dalam analisa ini proyeksi kebutuhan jangka panjang 120.000 ton/tahun. Hasil analisa kimia contoh pasir kuarsa daerah penelitian 
mengandung $\mathrm{SiO}_{2}$ lebih besar $85 \%$, maka pasir kuarsa di daerah penelitian memenuhi syarat sebagai bahan baku semen Portland.

\section{Kesimpulan}

1. Daerah penelitian pasir kuarsa terletak di daerah Bunne, Desa Kading, Kecamatan Tanete Riaja. Secara geografi daerah tersebut pada posisi: $4^{0} 31$ ' 15"- $4^{0} 31$ ' 45" Lintang Selatan dan $119^{0} 40^{\prime} 25^{\prime}$ - $119^{0} 40^{\prime}$ 50" Bujur Timur dari Greenwich. Pasir kuarsa tersebut berwarna putih keabuabuan, terkekarkan dengan intensitas rendah, tekstur klastik, berbuir pasir sedang sampai kasar, penggalian sedang sampai mudah perlu alat mekanis.

2. Endapan pasir kuarsa di daerah penelitian mempunyai penyebaran 30 ha. Analisa kimia contoh pasir kuarsa menunjukkan kadar $\mathrm{SiO}_{2}=(85-90) \%$, berat jenis 2,3. Komposisi mineralnya terdiri dari: kuarsa, feldspar, dan lempung. Endapan pasir kuarsa di daerah penelitian dapat digunakan sebagai bahan baku pengoreksi pembuatan semen Portland dan bahan bangunan konstruksi ringan.

3. Cadangan endapan pasir kuarsa di daerah penelitian terdiri dari cadangan terukur adalah 5.175.000 ton dengan mining recovery $90 \%$, sehingga cadangan layak tambang (mineable) $=4.657 .500$ ton. Jika produksi direncanakan 120.000 ton/tahun, maka umur tambang $=$ 38,81 tahun. . Hari kerja direncanakan 288 hari/tahun atau 24 hari/bulan dan jam kerja 8 jam/hari. sehingga produksi pasir kuarsa yang direncanakan 10.000 ton/bulan atau 416,66 ton/hari atau 52,08 ton/jam.

4. Penambangan yang cocok diterapkan adalah tambang terbuka dengan system teras-teras, penggalian dilakukan dengan metode back filling. Usulan penambangan pasir kuarsa meliputi: pembukaan tambang, pemindahan tanah penutup dan pengambilan pasir kuarsa, pemuatan dan pengangkutan, jalan tambang dan tata letak tambang.

5. Rencana pemasaran ke pasar domestic dan ekspor untuk bahan baku industri semen portland. Harga jual Rp 100.000 per ton logo gudang pabrik semen PT. Semen Tonasa Pangkep dan PT. Semen Bosowa Maros.

6. Kegiatan penambangan terdiri dari tahap persiapan, tahap operasi, dan tahap purna operasi. Kegiatan tersebut akan menimbulkan dampak terhadap perubahan tata guna lahan, vegetasi, morfologi, kualitas air dan udara, social ekonomi masyarakat. Kegiatan reklamasi pada tahap pasca tambang dan program pengembangan masyarakat lokal diharap dapat mengelola dampak yang timbul. Kegiatan pemantauan lingkungan dilakukan oleh pengusaha bersama dengan instansi terkait.

\section{Referensi}

Ardianto, V. M. (2017). Prioritas Pengendalian Resiko Lingkungan Dan Asuransi Lingkungan (Studi Pustaka Ekonomi Sumber Daya Alam). Gema Ekonomi, 6(2 Agustus), 919-928.

Cahyani, S. D., \& Aji, R. S. (2018). Strategi Pembangunan Berwawasan Lingkungan Kawasan Permukiman Segi Empat Emas Tunjungan Surabaya. Mintakat: Jurnal Arsitektur, 18(2).

Darwis Falah, 1993, Penyelidikan Geologi Terpadu Daerah Kabupaten Barru Propinsi Sulawesi Selatan, Ujung Pandang: Kanwil Departemen Pertambangan dan Energi Propinsi Sulawesi Selatan. 


\section{Muh. Darwis Falah, Sumber Daya Mineral Pasir Kuarsa}

Lefond, Stanley J., 1975, Industrial Mineral and Rock, New York: American Institute of Mining, Metallurgical, and Petrolium, Engineer, Inc.

Machali Muhsin, 1999, Klasifikasi Sumberdaya dan Cadangan, Bandung: Pusat Pengembangan Tenaga Pertambangan.

Otto Soemarwoto, 2004, Ekologi Lingkungan Hidup dan Pembangunan, Jakarta: Djambatan.

Rahmatillah, N., Nurhakim, N., \& Riswan, R. (2019). Estimasi Sumberdaya Dan Cadangan Batubara Rencana Pit Ab Pt Arutmin Indonesia Tambang Kintap Kabupaten Tanah Laut Kalimantan Selatan. Jurnal Himasapta, 3(02).

SNI 4726:2011 Tentang Pedoman Pelaporan, Sumberdaya, dan Cadangan Mineral.

Sukandarrumidi, 2004, Bahan Galian Industri, Yogyakarta: Gajah Mada University Press.

Sutardji. 2009. Sumberdaya Alam. Buku Ajar. Semarang: Fakultas Ilmu Sosial UNNES.

Suyanto, I., \& Utomo, A. S. (2013). Analisis Data Resistivitas Dipole-dipole Untuk Identifikasi Dan Perhitungan Sumber Daya Asbuton Di Daerah Kabungka, Pasarwajo, Pulau Buton, Sulawesi Tenggara (Halaman 1 sd 7). Jurnal Fisika Indonesia, 17(50).

Suyartono, 2003, Good Mining Practice, Pengelolaan Pertambangan yang Baik dan Benar, Semarang: Studi Nusa. 